\title{
Towards a Reference Model for After-Sales Service Processes
}

\author{
Elena Legnani, Stefano lerace and Sergio Cavalieri \\ University of Bergamo, Department of Industrial Engineering \\ Viale Marconi, 5 - I - 24044 Dalmine, Itaiy \\ e-mail: (elena.legnani, stefano.ierace, sergio.cavalieri)@unibg.it
}

\begin{abstract}
In the last years, given the high market pressure and the increased competition in several industries, the search for new business opportunity is focusing on service activities. After-Sales (AS) service has become increasingly important as a source of differentiation and market share for manufacturers and resellers, as well as a strategic driver for customer's retention. These changes often call for a new conceptual definition of the product-service bundle marketed to the final customer and for a thorough revision of the logistical and organizational configuration of the whole service chain. It comes out the necessity to design appropriate processes and to have a general and shared definition of their structure. Aim of the paper is to suggest a model which provides a common configuration of the assistance processes according to a framework that links the different typologies of assistance with the product service strategies offered by companies. Some case studies have been considered in order to validate the proposed framework and the model.
\end{abstract}

\section{Keywords}

After-Sales service, product service strategy, business process, performance measures

\section{Introduction}

Market competition has recently pushed companies to seek for other forms of competitiveness different from a traditional cost leadership strategy. The widening of geographic horizons due to the availability of communication technologies, the more pressing and specific requests of the final customers and the downfall of technological barriers are inducing manufacturing firms to look for new sources of competitive advantage (Thoben et al., 2001). In this context, companies are shifting from a product centric view to a more innovative customer centric one: their business role cannot be considered ending up with the transactional undertaking of product sale. They must strive their efforts in ensuring a long-lasting and stable relationship 
with the final customer through the overall product life-cycle by providing a valueadded portfolio of connected services. A bundle of tangible and intangible components extends the physical functionalities of the core product in order to fulfill the increasing requests of customization, uniqueness perception and variety demanded by the final customer (Rispoli and Tamma, 1992, Thobeh et al., 2001).

The AS service embraces a wide concept which spans several aspects: it is commonly referred to as either customer support, product support, or technical support and service (Goffin and New, 2001) and it has been acquiring a strategic role within companies' business. At first, it is a source of differentiation and revenue generation: for example, the profit margins are often higher than the ones obtained with the product sales and it may generate at least three times the turnover of the original purchase during a given product lifecycle (Alexander et al., 2002). Moreover, it affects the definition of the product service mix offered to the customer and the physical and organizational configuration of the overall logistics chain. Finally, it is also a power marketing force for promoting the brand of a company.

Since such a radical change of the strategic vision of AS service requires the design or the thorough reengineering of the service business processes (Hammer and Champy, 1993), their common understanding, their inherent activities, related performance metrics and best practices should be considered and properly assessed.

The present paper attempts to fill this necessity by proposing a model which aims at providing a comprehensive mapping of the AS service processes, with particular regard to the assistance ones. The paper is organized as follows: $\S 2$ is a literature review about the existing models used to map AS activities, $\$ 3$ reports a framework which links a product service strategy perspective to a technical support perspective and suggests a model to map the assistance processes while $\$ 4$ concerns the case studies used to test and validate both the framework and the model. Some conclusions and further developments are finally reported.

\section{Literature review}

A business process reference model aims at providing support for the solution of practical problems in reality and its purpose is the generalization and standardization of the processes and structures of a system: it integrates the concepts of business process reengineering, benchmarking and process measurement into a cross functional framework. With regard to the AS domain, what is really missing is a reference model which provides a clear and comprehensive definition of the processes and the activities making up a service chain.

Normally, the natural approach is to apply models from the manufacturing sector to the service one (Ellram et al., 2004). The most known product-based models adopted to describe service chains have been developed by Lee and Billington (1995), who analyze the flow of goods among suppliers, manufacturers and customers within an uncertain environment, Croxton et al. (2001), whose model conceptualizes a supply chain that includes the business processes, the management components and the structure of the chain and the Supply Chain Council (2006) which proposes the Supply Chain Operations Reference (SCOR) model to map the supply chain processes and their related metrics and best practice. 
On the other hand, focusing on service-based models specifically thought to represent service activities, in literature there are several approaches. They originate mainly in marketing and industrial engineering (Donabedian 1980; Edvardson, Olson 1996) or in the quality management area (Meffert, Bruhn 1995; Bullinger, Haischer, Renner 1994) and there are also a number of matrixes, describing how various characteristics of a service relate to each other (Johansson, 2003). However, it comes out that they have mainly a strategic approach and none of them focuses on the link between the supporting service strategies and the related processes structure.

As a result product-service models, which consider both tangible and intangible aspects as well as a strategic and an operational view, are required and their relating activities and performance metrics should be considered and properly defined. An attempt towards this necessity is the After Sales Chain Operations Reference (ASCOR) model proposed by Cavalieri et al. (2006) which has a limited applicability since it is focused just on a typology of assistance service (on-site support defined in section 3 of this paper) and the Customer Chain Operations Reference (CCOR) model defined by the Supply Chain Council (2006) which is still in an early development phase.

Table 1 reports a comparison among the quoted models considering their strength and weakness aspects from the service perspective. Despite the product-based models which can be roughly adapted to the service area, considering the models specifically designed for service, it turns out that the service-based models have mainly a strategic view while the current product-service models (such as ASCOR and $(C O R$ ) have an operational view which considers the processes associated to the service activities and their relating performance metrics.

Table 1. Comparison among the models from the service perspective

\begin{tabular}{|c|c|c|c|}
\hline & Model & Support for service & Weakness for service \\
\hline \multirow{3}{*}{ 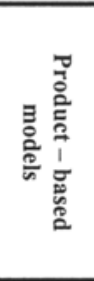 } & $\begin{array}{l}\text { Lee and Billington } \\
\text { (1995) }\end{array}$ & $\begin{array}{l}\text { It manages uncertainty and } \\
\text { it utilizes capacity levels } \\
\text { and flexibility versus } \\
\text { inventory. }\end{array}$ & $\begin{array}{l}\text { Services cannot be inventoried. The } \\
\text { model cannot easily address the } \\
\text { differences in quality of services. }\end{array}$ \\
\hline & $\begin{array}{l}\text { Croxton et al. } \\
(2001)\end{array}$ & $\begin{array}{l}\text { It utilizes a process view } \\
\text { to meet uncertain demand. }\end{array}$ & $\begin{array}{l}\text { It fits the product and component } \\
\text { flow of goods. }\end{array}$ \\
\hline & $\begin{array}{l}\text { SCOR model } \\
(2006)\end{array}$ & $\begin{array}{l}\text { Services are process } \\
\text { driven. }\end{array}$ & $\begin{array}{l}\text { The processes of make, deliver and } \\
\text { return do not fit services. }\end{array}$ \\
\hline 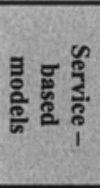 & $\begin{array}{l}\text { Donabedian } \\
\text { (1980), Edvardson } \\
\text { et al. (1996), } \\
\text { Meffert et } \\
\text { al.(1995), Bullinger } \\
\text { et al. (1994) }\end{array}$ & $\begin{array}{l}\text { They are mainly focused } \\
\text { on service strategies. }\end{array}$ & $\begin{array}{l}\text { They are not focused on service } \\
\text { processes and do not consider an } \\
\text { operational perspective. Performance } \\
\text { metrics are not provided. }\end{array}$ \\
\hline \multirow{2}{*}{ 를 $\frac{7}{5}$} & ASCOR (2006) & $\begin{array}{l}\text { It is focused on assistance } \\
\text { processes and their related } \\
\text { performance measures. }\end{array}$ & $\begin{array}{l}\text { It is limited since it considers just a } \\
\text { typology of assistance support and do } \\
\text { not focus on other service activities. It } \\
\text { does not consider service strategies. }\end{array}$ \\
\hline & CCOR (2006) & $\begin{array}{l}\text { It is focused on all the } \\
\text { service activities within the } \\
\text { customer interaction and } \\
\text { their related performance } \\
\text { measures. }\end{array}$ & $\begin{array}{l}\text { It considers a reactive support } \\
\text { neglecting a proactive perspective. }\end{array}$ \\
\hline
\end{tabular}




\section{Towards a reference model}

\subsection{Aligning product service strategies and assistance processes: a framework}

As highlighted from the literature review and shown in the Table 1, there is a lack of product-service models which associate a service strategic view with a more process-operational one. In this section, a framework which aligns the product service strategies with the required assistance supports has been created in order to facilitate companies in identifying their position and individualizing the key assistance processes to manage.

Focusing on the service strategies associated to a product, Lele (1997) states that any product can be assigned to one of four AS service segments. Considering low and high fixed costs (which occur regardless of the duration of equipment downtime) vs low and high variable costs (which change according to the duration of equipment downtime), these strategies are classified as follows: disposable, refers to products which do not cost much and when they are broken they are normally not repaired (like small household appliances and inexpensive office equipment); repairable, refers to products which need an assistance support but do not need to be repaired as soon as the problem occurs (like home $\mathrm{PCs}$ ); rapid response, refers to products which need to be repaired as soon as the problem occurs (like office PCs); never fail, refers to products where a failure is not an acceptable option for customers (such as medical equipment, airplanes, etc).

Regarding the processes to perform, Cavalieri and Corradi (2002) identify different typologies of support according to the service level offered, the level of involvement of the customer and the sustained costs. The supports can be:

- indirect support where the company provides an appropriate documentation to the customer who is able to autonomously perform the diagnosis, identification and application of the solution;

- remote support where the customer autonomously sorts out the problem with the help of an expert;

- off-site support where the company collects the faulty product through its assistance channel, it repairs and gives it back to the customer;

- on-site support where the customer is not able to solve the problem and needs the help of an expert who solves the problem at the location where the customer and the problem currently reside.

Next to these traditional forms of support, in the last years new ones have also been proposed: they are called proactive supports and are forms where the repair service or upgrade are scheduled by the company which provides the product. There are predictive maintenance techniques which help to determine the condition of the equipment in order to predict when an assistance support should be performed. There also forms of customised support that are developed according to specific customer requirements.

In Figure 1 an alignment between the product service strategies defined by Lele and the assistance supports is illustrated. 


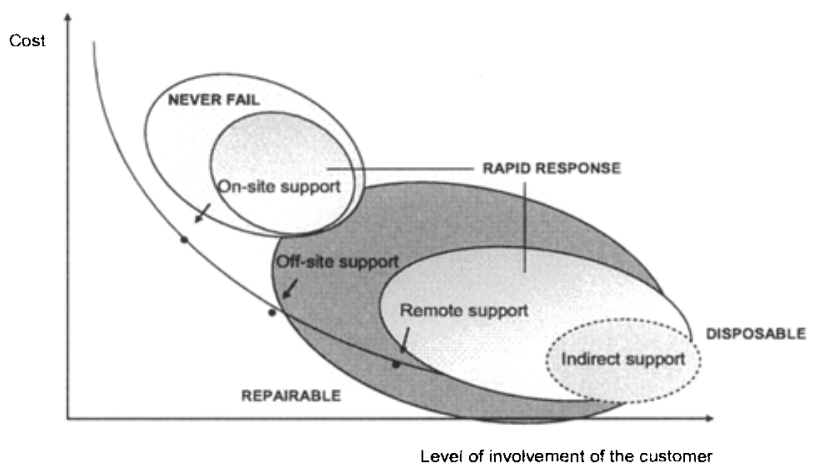

Fig. 1. Products and service support alignment

According to this framework, it results that:

- the never fail group embraces an on-site support since it normally refers to cumbersome products, with a very high capital value, that need a skilled technical support and thus repaired at the customer place;

- the rapid response group refers to products which need to be fixed promptly since they have high variable costs. On-site, remote or indirect supports are mainly performed;

- the repairable group includes indirect, remote or off-site supports since time bonds are not pressing. Even if products belonging to this group have a very high value, a repair is demanded but not necessarily immediate because the associated variable costs are not considerable;

- the disposable group may require an indirect support even if the low value of the associated products generally do not lead to any assistance support.

The proactive and the customised supports have not been considered within the work developed in this paper: this could lead to a further development of the model afterwards reported.

\subsection{Mapping assistance processes}

According to the product service strategies above mentioned, companies need a standard model to refer to while revising their AS processes which maps in detail how these processes can be performed and evaluated through the use of suitable indicators. This section reports in detail the processes associated to the assistance supports previously defined according to the same semantic structure of the Supply Chain Operations Reference (SCOR) model formalism. In order to provide an exhaustive and reliable structure, the model has been designed considering different scenarios coming from interviews in some companies and the suggestions and expertise of several industrial people. Furthermore, the ASCOR model and the CCOR model have been analyzed and integrated.

To understand the model structure, the processes are reported according to their assistance typology and, as an example, an insight of the off-site support process and its related performance metrics is depicted. 
Table 2. Assistance processes: definitions and metrics

\begin{tabular}{|c|c|c|c|}
\hline Indirect support & Remote support & On-site support & Off-site support \\
\hline $\begin{array}{l}\text {-Receive } \\
\text { Inquiry/Request } \\
\text {-Route Request } \\
\text {-Identify Solution } \\
\text {-Propose Solution } \\
\text {-Release Solution to } \\
\text { Customer } \\
\text {-Close Request }\end{array}$ & $\begin{array}{l}\text {-Receive } \\
\text { Inquiry/Request } \\
\text {-Route Request } \\
\text {-Identify Solution } \\
\text {-Propose Solution } \\
\text {-Distribute Solution - } \\
\text {-Release Solution to } \\
\text { Custóner } \\
\text {-Close Request }\end{array}$ & $\begin{array}{l}\text {-Receive } \\
\text { Inquiry/Request } \\
\text {-Route Request } \\
\text {-Schedule } \\
\text { On-Site Assist } \\
- \text {-Propose solution } \\
\text {-Obtain Materials } \\
\text {-Repair Product } \\
\text {-Dispose Materials } \\
\text {-Close Request }\end{array}$ & $\begin{array}{l}\text {-Receive } \\
\text { Inquin/Request } \\
\text {-Route Request } \\
\text {-Propose solution } \\
\text {-Repair Product } \\
\text {-Dispose Materiats } \\
\text {-Close Request }\end{array}$ \\
\hline \multicolumn{4}{|c|}{ Off-Site support process definition: "repair product" } \\
\hline \multicolumn{4}{|c|}{$\begin{array}{l}\text { - Repair Product: the process of preparing, decomposing the product, replacing the part } \\
\text { and re-assembling the product at the store/service center. }\end{array}$} \\
\hline \multicolumn{4}{|c|}{ Off-Site support performance metrics related to "repair product" process } \\
\hline \multicolumn{4}{|c|}{$\begin{array}{l}\text { - Annualized Service Event Rate: } n^{\circ} \text { of service calls per system per year; } \\
\text { - Customer Commit Resolution Time met: \% of time a customer problem/question is resolved } \\
\text { within the agreed upon time; } \\
\text { - First Time Fix Rate: } \% \text { of time the problem was fixed during the first contact with the customer; } \\
\text { - Repair Product Total Cost: Process costs; it includes direct and indirect cost. }\end{array}$} \\
\hline
\end{tabular}

\section{Case studies}

In order to validate the soundness of the proposed framework and to define the key assistance processes to map, three companies have been used as case studies. Figure 2 shows how product service strategy affects the processes management: each section of the diagram is filled with a different shade of grey according to the emphasis that each company gives to a specific process.

Company 1 performs a never fail strategy. It has three different manufacturing and commercial branches, it is present in more than 50 countries in the world and it provides products and service for folding carton, corrugated board and flexible materials markets. It has a widely range of machines, plants and spare parts. Since it has to provide a rapid and timely intervention, analysing its peculiar assistance processes, it comes out that the most important ones are typical of the on-site support, like the scheduling, the material obtaining and the product repair.

Company 2 refers to a rapid response strategy. It is an American multinational society involved in the computer science industry and it operates both in the hardware and in the software market. It offers facilities and IT service, personal computer, access equipment and solutions for imaging and printing. The example tested is about the support requested by a company operating in the express service field which needs an assistance support for 24 hours a day and for 7 days a week. In this case, it has been observed that as soon as the request is received it is fundamental to identify a rapid solution and correctly release it to the customer. This implies that an on-site support is often required; however, just in case of easily solvable failures, remote and indirect support are performed directly by the customer with the help of a company expert.

Company 3 is an example of repairable strategy. It is an Italian company which produces motorbikes. It has 8 plants in the world and it is present in more than 50 
different countries. In this case the service strategy does not require a very timely support, thus the company mainly offers an off-site support together with a remote and indirect support. This has been proved considering that for the company the most important processes are accomplished at the service center, like the solution proposal and the product repair.

The following table summarizes the results carried out from the analyzed case studies.

Fig 2. Case studies findings

\begin{tabular}{|c|c|c|c|}
\hline & $\begin{array}{l}\text { Company } 1 \\
\text { Never Fail }\end{array}$ & $\begin{array}{c}\text { Company } 2 \\
\text { Rapid response }\end{array}$ & $\begin{array}{l}\text { Company } 3 \\
\text { Repairable }\end{array}$ \\
\hline \multirow{3}{*}{ On-site support } & Schedule on-site & Schedule on-site & Schedule on-site \\
\hline & Obtain materials & Obtain materials & Obtain materials \\
\hline & Repair product & Repair product & Repair product \\
\hline \multirow{3}{*}{ Off-site support } & Route request & Route request & Route request \\
\hline & Repair product & Repair product & Repair product \\
\hline & Dispose materials & Dispose materials & Dispose materials \\
\hline \multirow{3}{*}{ Remote support } & Route request & Route request & Route request \\
\hline & Identify solution & Identify solution & Identify solution \\
\hline & Release solution & Release solution & Release solution \\
\hline \multirow{3}{*}{ Indirect support } & Identify solution & Identify solution & Identify solution \\
\hline & Propose solution & Propose solution & Propose solution \\
\hline & Release solution & Release solution & Release solution \\
\hline
\end{tabular}

\section{Conclusions and further developments}

This paper emphasizes the lack of suitable product-service models which consider both tangible and intangible aspects related to the AS area. For this reason, a framework which links product service strategies with assistance supports is proposed. Moreover, though in literature processes associated with the AS service have already been defined, their common understanding and a shareable structure should be properly defined. Thus a reference model has been suggested in order to map assistance activities. Summarizing, the proposed work could allow enterprises to: i) relate more coherently their AS strategy to their assistance operational processes and ii) identify the key processes to manage.

Further developments of this research could lead to the definition of a more complete standard reference model. On the one hand, the work could be addressed to additionally develop the assistance processes, including the proactive and customised supports and more specific performance metrics. On the other hand, the model could be enlarged in order to map all the AS activities linked to the interaction between the customer and the service provider. In this sense it is worthwhile mentioning the current research efforts within the Supply Chain Council, aiming to develop a framework encompassing the customer centred perspective (CCOR model), the process-service designer perspective (DCOR, Design Chain Operation Reference model) and the product-service supply chain management (SCOR model). 


\section{References}

Alexander W.L., Dayal S., Dempsey J.J., Vander Ark J.D. (2002), 'The secret life of factory service centers', The McKinsey Quarterly, No.3, pp. 106-115.

Bullinger H.J., Haischer M., Renner T. (1994), 'Qualitätsmanagement und Zertifizierung fördern den Unternehmenserfolg (in German), Computerworld Schweiz, Nr. 23/94, S. $1-4$.

Bundschuh R.G., Dezvane T.M. (2003), 'How to make after sales services pay off', The McKinsey Quarterly: The Online Journal of McKinsey \& Co., No.4 (http://www.mckinseyquartely.com).

Cavalieri S., Brun A., lerace S. (2006), 'After-Sales Processes in the SCOR model: a proposal and an empirical application', 14th Working Seminar on Production Economics, Vol.3, pp. 25-36.

Cavalieri S., Corradi E. (2002), 'L'evoluzione del servizio di assistenza del post-vendita: modelli di supporto, aspetti logistici ed opportunità IT (in Italian)', Atti del XXVIII Convengo Nazionale ANIMP, Spoleto 25-26 Ottobre.

Croxton K.L., Garcia-Dastugue S.J., Lambert D.M., Rogers D.L. (2001), The Supply Chain Management Process', The International Journal of Logistic Management, pp. 17-32.

Donabedian A. (1980), 'The definition of quality and approaches to its assessment. Explorations in quality assessment and monitoring', Health Administration, Ann ArborlMichigan.

Edvardson B., Olson J. (1996), 'Key concepts for new service development', The Service Industries Journal, April, Vol.16, No.2, pp. 140-164.

Ellram L.M., Tate W.L., Billington C. (2004), 'Understanding and managing the service supply chain', The Journal of Supply Chain Management, pp. 17-32.

Goffin K., New C. (2001), 'Customer support and new product development', International Journal of Operations and Production Management, 21 (3), 275-301.

Hammer M., Champy J. (1993), 'Reengineering the Corporation: A manifesto for business revolution', Harper Collins Publishers NY.

Johansson P., Olhager J (2003), 'Industrial service profiling: matching service offerings and processes', International Journal of Production Economics, 89, 309-320.

Lee H., Billington C. (1995), 'The evolution of Supply Chain Management Models and Practice at Hewlett-Packard', Interface, Vol.25, No.5, pp. 42-63.

Lele M. (1997), 'After-Sales service-necessary evil or strategic opportunity?', Managing Service Quality, Vol.7, No.3, pp. 141-145.

Meffert H., Bruhn M. (1995), 'Dienstleistungsmarketing: Grundlagen-KonzepteMethoden (in German)', Wiesbaden (Gabler).

Rispoli M., Tamma M. (1992), 'Beni e Servizi, cioè prodotti (in Italian)', Sinergie, n.28.

Supply Chain Council (2006), 'Supply Chain Operations Reference model, version 8.0', 'Customer Chain Operations Reference model', 'Design Chain Operations Reference model', www.supply-chain.org.

Thoben K.-D., Jagdev H., Eschenbaecher J. (2001), 'Extended Product: Evolving Traditional Product concepts', Proceedings of the 7th International Conference on Concurrent Enterprising: Engineering the Knowledge Economy through Co-operation, Bremen. 